\title{
The Prevalence and Types of Hypertensive Diseases in Pregnant Women Admitted to Department of Obstetrics and Gynecology in Tanta University Hospitals
}

\author{
AHMED A. ATTALLA, M.Sc.; GAMAL EL DEEN Y. EL KHOLI, M.D.; TAYMOUR M. ABDALLA, M.D. and \\ ABD EL GHAFFAR S. DAWOUD, M.D.
}

The Department of Obstetrics and Gynecology, Faculty of Medicine, Tanta University, Egypt

\begin{abstract}
Background: Hypertensive disorders of pregnancy are used as an umbrella term that includes chronic and gestational hypertension, preeclampsia and eclampsia, representing a major cause of maternal and perinatal morbidity and mortality, considered to be the most common medical problem encountered during pregnancy, and so this study was done to find the prevalence and types and the proper methods of treatment of each type of hypertension in pregnant women admitted to Department of Obstetrics, Tanta University Hospital.
\end{abstract}

Aim of Study: The aim of this study is to find the prevalence and types of hypertension in pregnant women admitted to Department of Obstetrics, Tanta University Hospital.

Patients and Methods: This prospective, randomized, comparative study included Seven hundred and fifty (750) pregnant women in the Department of Obstetrics and Gynecology in Tanta University Hospital during the period between December 2016 and December 2017. In this study, hypertensive pregnant females were categorized in to 4 major groups: Chronic hypertension, gestational hypertension, pre-eclampsia, eclampsia and no cases of superimposed pre-eclampsia on top of chronic hypertension were encountered. Informed consents were obtained from all study participants.

Results: Number of patients examined in this study was 750 pregnant women, 179 were hypertensive $(23.86 \%)$. Chronic hypertension 15 cases $(8.37 \%)$, gestational hypertension 61 cases $(34.07 \%)$, pre-eclampsia 90 cases $(50.27 \%)$ and eclampsia 13 cases $(7.26 \%)$, according to the clinical characteristics, the mean age was significally higher in chronic hypertensive group ( $40.53 \pm 5.3$ years), and was significally lower in eclamptic patients $(23.31 \pm 4.33$ years $)$, the highest gravidity was recorded in chronic hypertension $(3.20 \pm 0)$. The body mass index was similar in all the studied groups. Blood pressure was highest in preeclampsia, according to methods of delivery in different studied groups, assisted and spontaneous vaginal delivery were highest in gestational hypertension $(23 \%)$ and $(13.1 \%)$ respectively and Caesarian section was highest in eclampsia $(84.6 \%)$ and lowest in chronic hypertension $(60 \%)$, the gestational age of the studied groups was showing that prematurity was encountered in $61.54 \%$ of cases

Correspondence to: Dr. Ahmed A. Attalla, The Department of Obstetrics and Gynecology, Faculty of Medicine, Tanta University, Egypt of eclampsia and was lowest ( $0 \%)$ in chronic hypertension; this was due to induction of labor, the main cause of death in this study is prematurity. The mean APGAR score in the present study was highest in chronic hypertension group (7.40 $\pm 1.88)$ and lowest in eclamptic group (5.08 \pm 1.19$)$ after one minute of delivery and after 5 minutes APGAR score was highest in pre-eclamptic $(8.80 \pm 1.52)$ and lowest in eclamptic group ( $7.23 \pm 1.88)$. The respiratory distress syndrome, Neonatal Intensive Care Unit and neonatal mortality were highest in eclampsia group (3 8.5\%, 30.8\% and $23.1 \%$ respectively) and lowest in chronic hypertension group ( $0 \%$ in all), a comparison between 2 forms of pre-eclampsia (mild and severe) showed that all the parameters including blood pressure, hematocrit value, creatinine, uric acid levels and liver enzymes were higher in severe preeclampsia compared to the mild form. C.S was $100 \%$ in severe pre-eclampcia and $73.01 \%$ in mild pre-eclampcia, the respiratory distress syndrome, Neonatal Intensive Care Unit and neonatal mortality were significally higher in severe pre-eclampcia than mild pre-eclampcia, gestational age and birth weight were significally higher in severe pre-eclampcia than mild pre-eclampcia, Intra Uterine Growth Restrictions (I.U.G.R) were found only among the severe pre-eclampcia group (18.52\%).

Conclusions: From this study we can reach the following conclusions:

1- High blood pressure complicates $23.9 \%$ of all pregnant women.

2- The incidence of chronic hypertension in the present study is $8.37 \%$, gestational hypertension is $34.1 \%$, pre-eclampsia is $50.3 \%$ and eclampsia is $7.3 \%$.

3 - The worst prognosis was found among the eclamptic group.

4- Chronic hypertension when perfectly managed doesn't develop into superimposed pre-eclampsia.

5- No cases of secondary chronic hypertension were encountered in the study denoting that it is rare with pregnancy. The cause of secondary hypertension may compromise her fertility.

6- Neonatal complications were most common with preeclampsia and eclampsia.

Key Words: Hypertensive disorders - Pre-eclampsia - Eclampsia-Gestational hypertension. 


\section{Introduction}

HYPERTENSIVE disorders of pregnancy represent a major cause of maternal and perinatal morbidity and mortality. Hypertension is the most common medical problem encountered during pregnancy. It complicates $5 \%$ to $7 \%$ of all pregnancies $[\mathbf{1 , 2}]$.

The blood pressure depends on the work being done by the heart and the resistance of the blood vessels. The World Health Organization (WHO) suggests that the growth of the processed food industry has impacted the amount of salt in diets worldwide, and that this plays a role in hypertension. Hypertension in pregnancy and postpartum period is currently diagnosed by a Systolic Blood Pressure (SBP) greater than or equal $140 \mathrm{mmHg}$ and/or diastolic blood pressure greater than or equal to $90 \mathrm{mmHg}$. There is a need to reevaluate the usual thresholds of abnormal blood pressure values in pregnancy [3]. Evaluating blood pressure in late pregnancy and labor can help minimizing the complications and enabling the obstetrician to plan for the proper time and methods of interference and take the proper preparations and considerations for the next pregnancies.

\section{Aim of study:}

The aim of this study is to find the prevalence and types of hypertension in pregnant women admitted to Department of Obstetrics, Tanta University Hospital.

\section{Study design:}

This prospective, randomized, comparative study included Seven hundred and fifty (750) pregnant women in the Department of Obstetrics and Gynecology in Tanta University Hospital, hypertensive pregnant females were categorized in to 4 major groups: Chronic hypertension, gestational hypertension, pre-eclampsia, eclampsia and no cases of superimposed pre-eclampsia on top of chronic hypertension were encountered. Informed consents were obtained from all study participants.

\section{Patients and Methods}

This study included Seven hundred and fifty (750) pregnant women in the Department of Obstetrics and Gynecology in Tanta University Hospital during the period between December 2016 and December 2017. In this study, hypertensive pregnant females were categorized in to 4 major groups: Chronic hypertension, gestational hypertension, pre-eclampsia, eclampsia and no cases of superimposed pre-eclampsia on top of chronic hypertension were encountered.

Inclusion criteria include: Age from 16 to 42 years old, both primi-gravida and multigravida, including all pregnant females admitted the department.

Exclusion criteria include: Diabetic patients or any other chronic diseases with pregnancy.

\section{Results}

\section{Statistical analysis:}

Data were fed to the computer and analyzed using IBM SPSS software package version 20.0. (Armonk, NY: IBM Corp) Qualitative data were described using number and percent. The Kolmogorov-Smirnov test was used to verify the normality of distribution Quantitative data were described using range (minimum and maximum), mean, standard deviation and median. Significance of the obtained results was judged at the $5 \%$ level.

The used tests were:

1- Chi-square test: For categorical variables, to compare between different groups.

2- Fisher's Exact or Monte Carlo correction: Correction for chi-square when more than $20 \%$ of the cells have expected count less than 5 .

3- F-test (ANOVA): For normally distributed quantitative variables, to compare between more than two groups.

4- Kruskal Wallis test: For abnormally distributed quantitative variables, to compare between more than two studied groups.

Number of patients examined in this study was 750 pregnant women, 179 were hypertensive (23.86\%). Chronic hypertension 15 cases $(8.37 \%)$, gestational hypertension 61 cases $(34.07 \%)$, preeclampsia 90 cases $(50.27 \%)$ and eclampsia 13 cases $(7.26 \%)$.

The mean age was significally higher in chronic hypertensive group ( $40.53 \pm 5.3$ years), and was significally lower in eclamptic patients $(23.31 \pm 4.33$ years). Gravidity; the highest gravidity was recorded in chronic hypertension (3.20 \pm 0$)$. The body mass index was similar in all the studied groups. Blood pressure was highest in preeclampsia.

Assisted and spontaneous vaginal delivery were highest in gestational hypertension $(23 \%)$ and $(13.1 \%)$ respectively and Caesarian section was 
highest in eclampsia (84.6\%) and lowest in chronic hypertension $(60 \%)$.

Prematurity was encountered in $61.54 \%$ of cases of eclampsia and was lowest $(0 \%)$ in chronic hypertension; this was due to induction of labor.

The main cause of neonatal death is prematurity. The mean APGAR score in the present study was highest in chronic hypertension group (7.40 \pm 1.88$)$ and lowest in eclamptic group $(5.08 \pm 1.19)$ after one minute of delivery and after 5 minutes APGAR score was highest in pre-eclamptic $(8.80 \pm 1.52)$ and lowest in eclamptic group $(7.23 \pm 1.88)$. The respiratory distress syndrome, Neonatal Intensive Care Unit and neonatal mortality were highest in eclampsia group $(38.5 \%, 30.8 \%$ and $23.1 \%$ respec- tively) and lowest in chronic hypertension group $(0 \%$ in all).

All the parameters including blood pressure, hematocrit value, creatinine, uric acid levels and liver enzymes were higher in severe preeclampsia compared to the mild form; C.S was $100 \%$ in severe pre-eclampcia and $73.01 \%$ in mild preeclampcia. Respiratory distress syndrome, neonatal intensive care unit and neonatal mortality were significally higher in severe pre-eclampcia than mild pre-eclampcia, gestational age and birth weight were significally higher in severe pre-eclampcia than mild pre-eclampcia and Intra Uterine Growth Restrictions (I.U.G.R) were found only among the severe pre-eclampcia group $(18.52 \%)$.

Table (1): Clinical characteristics of studied patients.

\begin{tabular}{|c|c|c|c|c|c|c|}
\hline & $\begin{array}{c}\text { Chronic } \\
\text { hypertension } \\
(n=15)\end{array}$ & $\begin{array}{l}\text { Gestational } \\
\text { hypertension } \\
(n=61)\end{array}$ & $\begin{array}{l}\text { Pre- } \\
\text { eclampsia } \\
(\mathrm{n}=90)\end{array}$ & $\begin{array}{l}\text { Eclampsia } \\
\quad(n=13)\end{array}$ & $\begin{array}{l}\text { Test } \\
\text { of sig. }\end{array}$ & $p$ \\
\hline $\begin{array}{l}\text { Age (years): } \\
\text { Range } \\
\text { Mean } \pm \text { SD }\end{array}$ & $\begin{array}{l}32.0-42.0 \\
39.53 \pm 2.30\end{array}$ & $\begin{array}{l}17.0-38.0 \\
27.25 \pm 3.20\end{array}$ & $\begin{array}{l}18.0-35.0 \\
20.08 \pm 1.75\end{array}$ & $\begin{array}{l}16.0-34.0 \\
23.31 \pm 4.33\end{array}$ & $\begin{array}{l}\mathrm{F}= \\
66.587^{*}\end{array}$ & $<0.001 *$ \\
\hline $\begin{array}{l}\text { Gravidity: } \\
\text { Range } \\
\text { Mean } \pm \text { SD }\end{array}$ & $\begin{array}{l}2.0-3.0 \\
2.80 \pm 0.41\end{array}$ & $\begin{array}{l}1.0-1.0 \\
1.0-1.0\end{array}$ & $\begin{array}{l}1.0-1.0 \\
1.0-1.0\end{array}$ & $\begin{array}{l}1.0-1.0 \\
1.0-1.0\end{array}$ & $\begin{array}{l}\mathrm{H}= \\
177.782 *\end{array}$ & $<0.001 *$ \\
\hline $\begin{array}{l}\text { Parity: } \\
\quad \text { Range } \\
\text { Mean } \pm \mathrm{SD}\end{array}$ & $\begin{array}{l}2.0-5.0 \\
3.5 \pm 0.53\end{array}$ & $\begin{array}{l}- \\
-\end{array}$ & $\begin{array}{l}- \\
-\end{array}$ & $\begin{array}{l}- \\
-\end{array}$ & - & - \\
\hline $\begin{array}{l}\text { Abortion: } \\
\text { Range } \\
\text { Mean } \pm \text { SD }\end{array}$ & $\begin{array}{l}1.0-1.0 \\
1.0 \pm 0.0\end{array}$ & $\begin{array}{l}- \\
-\end{array}$ & $\begin{array}{l}- \\
-\end{array}$ & $\begin{array}{l}- \\
-\end{array}$ & - & - \\
\hline $\begin{array}{l}\text { BMI }\left(\mathrm{kg} / \mathrm{m}^{2}\right): \\
\text { Range } \\
\text { Mean } \pm \text { SD }\end{array}$ & $\begin{array}{l}26.0-32.70 \\
28.81 \pm 2.01\end{array}$ & $\begin{array}{c}16.90-35.0 \\
27.31 \pm 3.37\end{array}$ & $\begin{array}{l}16.20-34.90 \\
26.77 \pm 3.92\end{array}$ & $\begin{array}{l}16.0-34.10 \\
25.10 \pm 5.91\end{array}$ & $\begin{array}{l}\mathrm{F}= \\
2.476\end{array}$ & 0.063 \\
\hline
\end{tabular}

Table (2): Methods of delivery in the different studied groups.

\begin{tabular}{|c|c|c|c|c|c|c|c|c|c|c|}
\hline & \multicolumn{2}{|c|}{$\begin{array}{c}\text { Chronic } \\
\text { hypertension } \\
(\mathrm{n}=15)\end{array}$} & \multicolumn{2}{|c|}{$\begin{array}{c}\text { Gestational } \\
\text { hypertension } \\
(\mathrm{n}=61)\end{array}$} & \multicolumn{2}{|c|}{$\begin{array}{c}\text { Pre- } \\
\text { eclampsia } \\
(\mathrm{n}=90)\end{array}$} & \multicolumn{2}{|c|}{$\begin{array}{l}\text { Eclampsia } \\
(\mathrm{n}=13)\end{array}$} & \multirow[t]{2}{*}{$x^{2}$} & \multirow[t]{2}{*}{$\mathrm{MC}_{p}$} \\
\hline & No. & $\%$ & No. & $\%$ & No. & $\%$ & No. & $\%$ & & \\
\hline *Spontaneous vaginal delivery & 5 & 33.3 & 15 & 24.6 & 10 & 11.1 & 0 & 0.0 & $11.710^{*}$ & $0.044 *$ \\
\hline *Assisted vaginal delivery & 1 & 6.7 & 7 & 11.58 & 7 & 7.8 & 2 & 15.38 & & \\
\hline${ }^{*}$ C.S & 9 & 60.0 & 39 & 63.9 & 73 & 81.1 & 11 & 84.6 & & \\
\hline
\end{tabular}

Table (3): Gestational age at delivery in the studied groups.

\begin{tabular}{|c|c|c|c|c|c|c|c|c|c|c|}
\hline \multirow[t]{2}{*}{$\begin{array}{l}\text { Gestational age } \\
\text { at delivery }\end{array}$} & \multicolumn{2}{|c|}{$\begin{array}{c}\text { Chronic } \\
\text { hypertension } \\
(\mathrm{n}=15)\end{array}$} & \multicolumn{2}{|c|}{$\begin{array}{l}\text { Gestational } \\
\text { hypertension } \\
(\mathrm{n}=61)\end{array}$} & \multicolumn{2}{|c|}{$\begin{array}{c}\text { Pre- } \\
\text { eclampsia } \\
(\mathrm{n}=90)\end{array}$} & \multicolumn{2}{|c|}{$\begin{array}{l}\text { Eclampsia } \\
\quad(n=13)\end{array}$} & \multirow[t]{2}{*}{$x^{2}$} & \multirow[t]{2}{*}{$p$} \\
\hline & No. & $\%$ & No. & $\%$ & No. & $\%$ & No. & $\%$ & & \\
\hline - Full-term ( $\geq 37$ weeks) & (15) & 100 & $(55)$ & 90.16 & $(73)$ & 81.11 & (5) & 38.46 & 18.745 & $<0.001 *$ \\
\hline $\begin{array}{l}\text { - Pre-mature }(<37 \text { weeks) } \\
\text { (induced preterm labour }\end{array}$ & $(0)$ & 0 & (6) & 9.84 & (17) & 18.89 & (8) & 61.54 & $18.745^{*}$ & $<0.001 *$ \\
\hline
\end{tabular}


Table (4): Neonatal outcome in different studied groups.

\begin{tabular}{|c|c|c|c|c|c|c|c|c|c|c|}
\hline \multirow[b]{2}{*}{$\begin{array}{l}\text { APGAR score after lmin: } \\
\quad \text { Mean } \pm \text { SD }\end{array}$} & \multicolumn{2}{|c|}{$\begin{array}{c}\text { Chronic } \\
\text { hypertension } \\
(\mathrm{n}=15)\end{array}$} & \multicolumn{2}{|c|}{$\begin{array}{c}\text { Gestational } \\
\text { hypertension } \\
(\mathrm{n}=61)\end{array}$} & \multicolumn{2}{|c|}{$\begin{array}{c}\text { Pre- } \\
\text { eclampsia } \\
(\mathrm{n}=90)\end{array}$} & \multicolumn{2}{|c|}{$\begin{array}{l}\text { Eclampsia } \\
(\mathrm{n}=13)\end{array}$} & $\begin{array}{l}\text { Test } \\
\text { of sig. }\end{array}$ & $p$ \\
\hline & \multicolumn{2}{|c|}{$7.40 \pm 1.88$} & \multicolumn{2}{|c|}{$7.31 \pm 1.77$} & \multicolumn{2}{|c|}{$7.37 \pm 1.90$} & \multicolumn{2}{|c|}{$5.08 \pm 1.19$} & $\mathrm{~F}=6.315^{*}$ & $<0.001 *$ \\
\hline \multirow[t]{2}{*}{$\begin{array}{l}\text { After 5mins: } \\
\quad \text { Mean } \pm \text { SD }\end{array}$} & \multicolumn{2}{|c|}{$8.07 \pm 2.02$} & \multicolumn{2}{|c|}{$7.77 \pm 1.90$} & \multicolumn{2}{|c|}{$8.80 \pm 1.52$} & \multicolumn{2}{|c|}{$7.23 \pm 1.88$} & $\mathrm{~F}=6.159 *$ & $<0.001 *$ \\
\hline & $\mathrm{N}$ & $\%$ & $\mathrm{~N}$ & $\%$ & $\mathrm{~N}$ & $\%$ & $\mathbf{N}$ & $\%$ & $x^{2}$ & $\mathrm{MC}_{p}$ \\
\hline - Respiratory distress syndrome & 0 & 0 & 8 & 13.1 & 9 & 10.0 & 5 & 38.5 & 0.729 & 0.876 \\
\hline $\begin{array}{l}\text { - Neonatal Intensive Care Unit } \\
\text { (NICU) }\end{array}$ & 0 & 0 & 11 & 18 & 23 & 25.6 & 4 & 30.8 & 2.211 & 0.525 \\
\hline - Neonatal death & 0 & 0 & 4 & 6.6 & 10 & 11.1 & 3 & 23.1 & 1.426 & 0.715 \\
\hline
\end{tabular}

Table (5): Clinical and laboratory characteristics and pregnancy outcome in mild and severe pre-eclampsia.

\begin{tabular}{|c|c|c|c|c|}
\hline & $\begin{array}{c}\text { Mild } \\
\text { pre-eclampsia } \\
(\mathrm{n}=63)\end{array}$ & $\begin{array}{c}\text { Severe } \\
\text { pre-eclampsia } \\
(\mathrm{n}=27)\end{array}$ & Test of sig. & $p$-value \\
\hline $\begin{array}{l}\text { Age (years): } \\
\quad \text { Mean } \pm \mathrm{SD}\end{array}$ & $29.44 \pm 5.54$ & $28.37 \pm 3.20$ & $t=0.070$ & 0.945 \\
\hline $\begin{array}{r}B M I\left(\mathrm{~kg} / \mathrm{m}^{2}\right): \\
\text { Mean } \pm \mathrm{SD}\end{array}$ & $27.46 \pm 2.37$ & $26.25 \pm 5.59$ & $t=1.066$ & 0.295 \\
\hline $\begin{array}{l}\text { Blood pressure Systolic: } \\
\quad \text { Mean } \pm \text { SD }\end{array}$ & $149.29 \pm 6.14$ & $170.81 \pm 6.20$ & $t=6.729$ & $<0.001 *$ \\
\hline $\begin{array}{l}\text { Diastolic: } \\
\quad \text { Mean } \pm \mathrm{SD}\end{array}$ & $96.03 \pm 4.95$ & $115.44 \pm 3.29$ & $t=9.468^{*}$ & $<0.001 *$ \\
\hline Hematocrit value & $37.29 \pm 2.35$ & $44.58 \pm 2.84$ & $t=5.710^{*}$ & $<0.001 *$ \\
\hline $\begin{array}{l}\text { Platelet: } \\
\quad \text { Count }\left(* 10^{3} / \mathrm{ul}\right)\end{array}$ & $248.4 \pm 68.2$ & $149.27 \pm 86.4$ & $t=5.820^{*}$ & $<0.001 *$ \\
\hline $\begin{array}{l}\text { Creatinine }(\mathrm{mg} / \mathrm{dl}) \text { : } \\
\quad \text { Mean } \pm \mathrm{SD}\end{array}$ & $0.64 \pm 0.14$ & $0.95 \pm 0.22$ & $t=6.919 *$ & $<0.001 *$ \\
\hline $\begin{array}{l}\text { Uric acid Mg/dl: } \\
\text { Mean } \pm \text { SD }\end{array}$ & $4.56 \pm 0.94$ & $7.03 \pm 0.88$ & $t=2.188^{*}$ & $0.031 *$ \\
\hline $\begin{array}{l}\text { Liver function tests: } \\
\text { ALT u/l } \\
\text { AST u/l }\end{array}$ & $\begin{array}{l}14.74 \pm 3.93 \\
24.14 \pm 2.56\end{array}$ & $\begin{array}{l}54.54 \pm 30.73 \\
40.34 \pm 10.83\end{array}$ & $\begin{array}{l}t=10.162 * \\
t=11.239 *\end{array}$ & $<0.001 *$ \\
\hline $\begin{array}{l}\text { Induction of labor } \\
\text { Caesarian section }\end{array}$ & $\begin{array}{l}6(9.5 \%) \\
46(73.01 \%)\end{array}$ & $\begin{array}{l}1(3.7 \%) \\
27(100 \%)\end{array}$ & $\begin{array}{l}\chi_{2}^{2}=0.893 \\
\chi^{2}=8.982 *\end{array}$ & $\begin{array}{l}\mathrm{FE} p=0.670 \\
0.003 *\end{array}$ \\
\hline Gestational age at delivery & $36 \pm 2.2$ & $34.7 \pm 3.1$ & $t=2.261 *$ & $0.026^{*}$ \\
\hline Birth weight & $2648 \pm 810.2$ & $2154 \pm 649.2$ & $t=2.803 *$ & $0.006^{*}$ \\
\hline Admission of N.I.C.U. & $9(14.28 \%)$ & $14(51.85 \%)$ & $\chi_{2}^{2}=14.020^{*}$ & $<0.001 *$ \\
\hline Respiratory distress syndrome & $2(3.2 \%)$ & $7(25.92 \%)$ & $\chi_{2}^{2}=10.870^{*}$ & $\mathrm{FE}_{p=0.003 *}$ \\
\hline Neonatal death & $2(3.17 \%)$ & $8(29.62 \%)$ & $\chi_{2}^{2}=13.393$ & $\mathrm{FE}_{p=0.001 *}$ \\
\hline Intra uterine growth restrictions & $0(0 \%)$ & $5(18.52 \%)$ & $\chi^{2}=10.233$ & $\mathrm{FE}_{p=0.001} *$ \\
\hline
\end{tabular}

\section{Discussion}

In this study the comparison between the 4 groups was done according to multiple clinical characteristics including (age, gravidity, parity, abortion rate, body mass index, hemoglobin percentage and blood pressure).
In the present study the most frequent type of hypertension with pregnancy was the pre-eclampsia 90 cases $(50.27 \%)$, then gestational hypertension 61 cases $(34.07 \%)$, chronic hypertension 15 cases $(8.37 \%)$, and the least was the eclamptic group 13 cases $(7.26 \%)$, our results were with agreement with that of Assis et al., who found that the most 
frequent type was pre-eclampsia 63 cases $(48.8 \%)$, gestational hypertension 24 cases $(18.6 \%)$ and chronic hypertension 8 cases $(6.2 \%)$ and the only difference was that there was no eclamptic cases recorded in Assis et al., study [4]

In the present study the incidence of hypertensive disorders was found to be $(23.9 \%)$ out of the whole pregnant females compared to $(15 \%)$ in the study of Payne et al., while in Assis et al., study it was $(14.5 \%)$, and in another study by Mehta et al., it was $(6.9 \%)$ and $(16.2 \%)$ in the study by berhe et al. [4-7].

This study revealed that $(46.7 \%)$ of chronic hypertensive females and $(57.3 \%)$ of the severe hypertensive females (involving pre-eclamptic and eclamptic groups) had induced preterm deliveries with gestational age less than (37) weeks compared to $34 \%$ and $70 \%$ respectively in the study by Seely et al., $19.4 \%$ and $27.7 \%$ respectively in the study of Atika et al., [7,8].

The incidence of superimposed pre-eclapmsia in the chronic hypertension is $(26.4 \%)$ in the study of Guida et al., but in the present study we didn't encounter the superimposed pre-eclampsia because we treated chronic hypertension from the start of pregnancy [9].

In our study the gravidity was ranging from 23 and the parity was 2-5 in the chronic hypertension with pregnancy. Other types of hypertension with pregnancy were primi-gravidae. This is in agreement with the study by Assis et al. [4]

Body Mass Index (BMI) in the present study, gestational hypertension was 16.90 to 35.0 . In preeclampsia and eclampsia it was 16.20 to 34.90 and 16.0 to 34.10 respectively. In chronic hypertension it was 26.0 to 32.70. The Body Mass Index (BMI) was 15.70 to $36.90,14.33$ to $33.0,15.20$ to 34.40 and 28.20 to 33.37 respectively. This is in agreement with Mrema et al. [10]

The incidence of caesarian section in preeclamptic group in the present study was $81.1 \%$, while in the study of Guida et al., it was 72\% [9]

Eclamptic cases recorded the highest percentage in neonatal deaths $23.1 \%$, while in pre-eclamptic and gestational hypertension was 11.1 and $6.6 \%$ respectively, and $0 \%$ in chronic hypertension, the study by Barbosa et al., recorded 23.88\%, 14.36\% and $19.45 \%$ respectively for respiratory distress syndrome and $26.87 \%, 11.26 \%$ and $15.78 \%$ respectively for neonatal death [11].
In this study, the neonatal deaths was significantly higher in severe pre eclampsia being $29.62 \%$ compared to $3.17 \%$ in mild form, Parveen et al., recorded them as $0.63 \%$ and $0.11 \%$ respectively [12].

Parveen et al., reported $8.6 \%$ intra uterine fetal demise in severe pre-eclamptic group and $2.15 \%$ still births whereas our study stated $18.52 \%$ intra uterine fetal demise among the same group with no cases of still births [12]

There were no neonatal deaths or respiratory distress syndrome and no admission to the neonatal intensive care in the chronic hypertension group; this was reported by Parveen et al., [12]

\section{Conclusion:}

From this study we can reach the following conclusions:

1- High blood pressure complicates $23.9 \%$ of all pregnant women.

2- The incidence of chronic hypertension in the present study is $8.37 \%$, gestational hypertension is $34.1 \%$, pre-eclampsia is $50.3 \%$ and eclampsia is $7.3 \%$.

3- The worst prognosis was found among the eclamptic group.

4- Chronic hypertension when perfectly managed doesn't develop into superimposed preeclampsia.

5- No cases of secondary chronic hypertension were encountered in the study denoting that it is rare with pregnancy. The cause of secondary hypertension may compromise her fertility.

6- Neonatal complications were most common with pre-eclampsia and eclampsia.

\section{References}

1- NESS R. and ROBERTS J.: Epidemiology of hypertension. In: Lindheimer, Roberts M. and Cunningham F. (editors). Chesley's Hypertensive Disorders in Pregnancy, 2nd ed. Stamford, Connecticut: Appleton \& Lange, 43, 1999.

2- VILLAR J., SAY L. and GULMEZOGLU A. : Preeclampsia eclampsia: A health problem for 2000 years. In: Critchly H, MacLean A, Poston L. (editors). Preeclampsia. $3^{\text {rd }}$ edition London, England: RCOG Press, 189-207, 2003.

3- GIUSEPPE M., FAGARD R. and NARKIEWЮZ K. Guidelines for the management of arterial hypertension: The Task Force for the management of arterial hypertension of the European Society of Hypertension (ESH) and of the European Society of Cardiology (ESC)". European Heart Journal, 34: 2159, 2013. 
4- ASSIS T., VIANA F. and RASSI S.: Study on the major maternal risk factors in hypertensive syndromes. Arq Bras Cardiol., 91: 11, 2008.

5- PAYNE J.: Hypertension in pregnancy. Medical professionals, 3: 18, 2016.

6- MEHTA B., KUMAR V., CHAWLA S., SACHDEVA S. and MAHOPATRA D.: Hypertension in Pregnancy: A Community-Based Study, 40: 273, 2015.

7- SEELY E. and ECKER J.: Chronic Hypertension in Pregnancy. Circulation, 129: 1254, 2014.

8- ATIKA A., REEM B. and ABDELMONEIM E.: Neonatal Outcome in Hypertensive Disorders of Pregnancy in a Tertiary Neonatal Unit in Sudan. Journal of Medicine and Medical Research, 2: 59, 2014.
9- GUIDA J., PARPINELLI M. and SURITA F.: The impact of proteinuria on maternal and perinatal outcomes among women with pre-eclampsia Int. J. Gynecol. Obstet., 13: $1,2018$.

10- MREMA D., LIE R. and DALTVEIT A.: The association between pre pregnancy body mass index and risk of preeclampsia; BMC Pregnancy Childbirth, 18, 2018.

11-BARBOSA I., SILVA W. and CERQUEIRA W.: Maternal and fetal outcome in women with hypertensive disorders of pregnancy: The impact of prenatal care. Therapeutic advances in cardiovascular disease, 9: 140, 2015.

12- PARVEEN M., AABIDHA G., EMMANUEL P. and JASMIN H.: Maternal and fetal outcome in pre-eclampsia in a secondary care hospital in South India, Family Med. Prim. Care, 4: 56, 2015. 


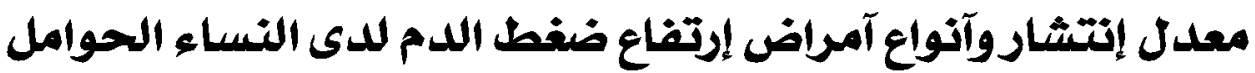

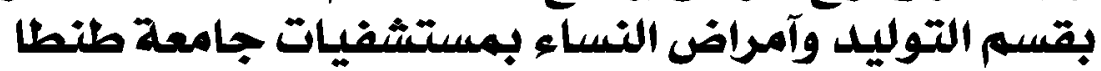

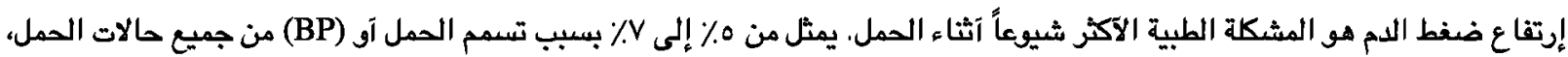

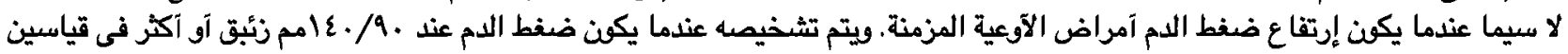

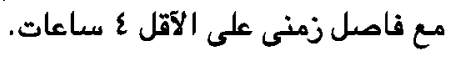

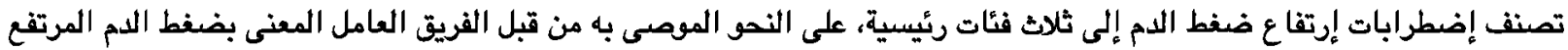

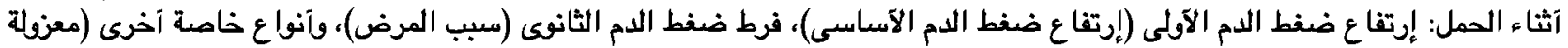

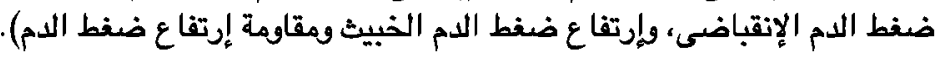



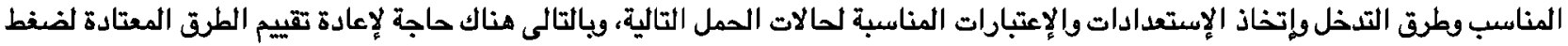

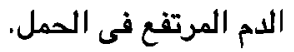

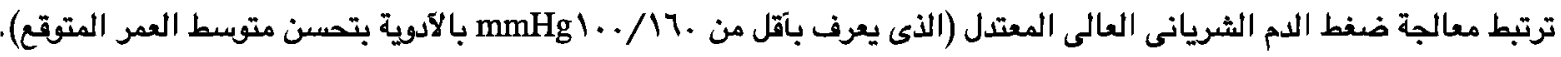

تهدف هذه الدراسة إلى معرفة معدل إنتشار وآنواع ضغط الدم فى الحوامل المقبولين بقسم التوليد فى مستشفيات جامعة طنطا.


مجموعات: المجموعات المزمنة وضغط الدمام الحملى وما قبل الإرتجاعية والإرتجاعية. ألم يتم تسجيل آى حالات من مقدمات الإرتجاع المتراكبة فوق فرط ضفط الدم المزمن فى دراستنا الحالية. تم تقدير عمر الحمل من خلال آخر دودة شهرية وفحص الموجات فوق الصوتئية

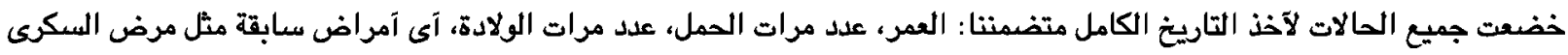

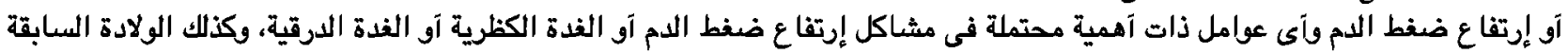

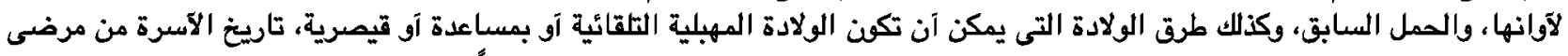

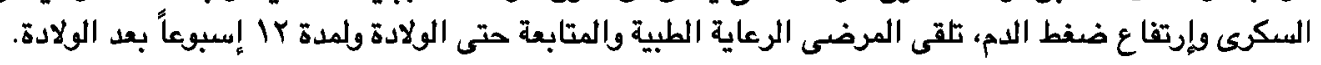

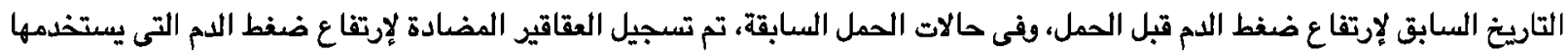

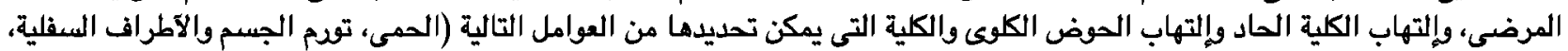

بول دموى، قلة البول).

تم تشخيص هذه المجموعات الآريع على النحو التالى:

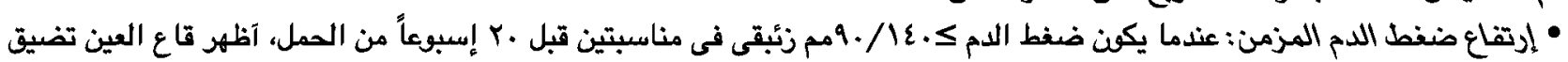

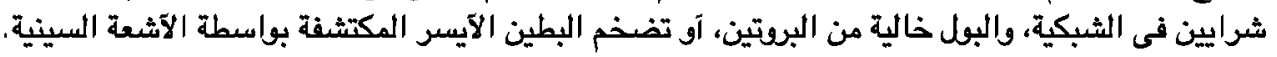

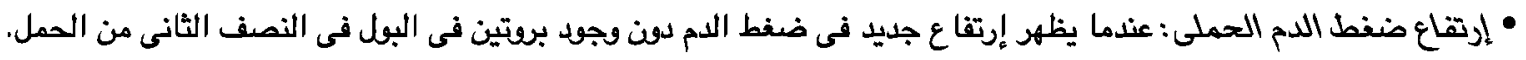

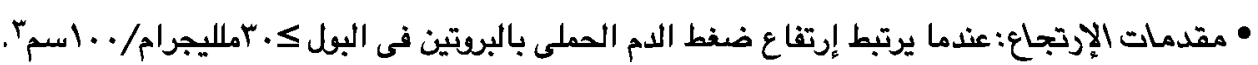
• الإرتجاع: عندما يعانى مرضى ما قبل تسمم الحمل من تشنجات و/آو غييوبة بعد إستبعاد جميع الآسباب الآخرى اللنوبات وإلغييوبة. تم إجراء معدل النبض ودرجة الحرارة وفحص الصدر والقلب لكل مريض.

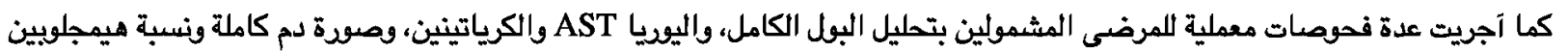

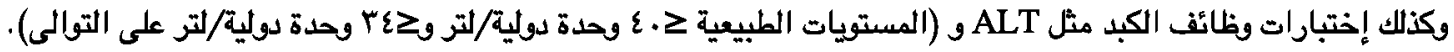
تم إجراء فحص قاع العين اللتاكك من تشخيص إرتفاع ضغط الدم المزمن من آجل البحث عن آى تغير مثل التقلص آو التوم آو تغيرات تصلب الشرايين.

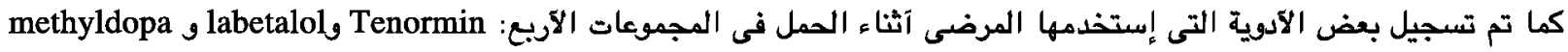



